\title{
Metode Dakwah Pada Kalangan Lanjut Usia Di Masjid Al- Furqon Haurgeulis
}

\author{
Moh. Khofifi ${ }^{1}$, Sobirin ${ }^{2}$ \\ 1,2 Institut Agama Islam Az-Zaytun Indonesia (IAI Al-AZIS) Gantar Indramayu
}

\begin{tabular}{|c|c|}
\hline Article Info & ABSTRACT \\
\hline Article history: & Elderly people are every Indonesian citizen, male and female, who have \\
\hline Received, Februari 17, 2019 & $\begin{array}{l}\text { reached the age of } 60 \text { years and over, whether they have the potentially or not } \\
\text { (The decree of the Minister of Social affair of RI No.15/HUK/2007). The }\end{array}$ \\
\hline Accepted, April 3, 2019 & objectives of this study are to determine the use of da'wah method for elderly \\
\hline Keywords: & $\begin{array}{l}\text { elderly people at Al-Furqon Mosque. This study applies a qualitative method } \\
\text { (field research) for data collection, this study employs structured interview, } \\
\text { observation and documentation techniques. The findings of the study show }\end{array}$ \\
\hline Method & that there is no specific recitation for elderly people at Al-Furqon Mosque \\
\hline Da'wah, Elderly & almost middle age. Routine recitation is held once a week on Sunday night \\
\hline Masjid Al-Furqon & and Wednesday night. It implements lecturing, holding question and answer \\
\hline Haurgeulis & $\begin{array}{l}\text { and applicative methods. And the second finding, supporting factors of } \\
\text { conducting da'wah to elderly people it shows adequate facilities and } \\
\text { infrastructure, the right time table this activity, is after Maghrib mass prayer, } \\
\text { the use of local languages as means of communication to the send the da'wah } \\
\text { message from the preacher, The tolerance of other groups or organizations } \\
\text { that are contrary to the culture of the Al-Furqon Mosque, lastly the family } \\
\text { support of the elderly people who always motivaty them to be "Istiqomah" in } \\
\text { joining the recitation at family and the inhibiting factor in delivering the } \\
\text { message of da'wah to elderly worshipers in terms of psychological and } \\
\text { physical perspectives. Are from the psychological lonely, mourning the loss } \\
\text { of a loved one and feel depression due to pressure from family. Are from a } \\
\text { physical perspective, they experience decreased hearing ability, decreased } \\
\text { vision, and immune system that is getting weaker so they are susceptible to } \\
\text { disease. So rarely can take part in recitation. }\end{array}$ \\
\hline
\end{tabular}

This is an open access article under the $\underline{C C B Y-S A}$ license.

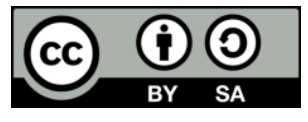

Corresponding Author:

Moh. Khofifi, Sobirin

Institut Agama Islam Az-Zaytun Indonesia (IAI Al-AZIS) Gantar Indramayu

Email: khofifimoh03@gmail.com

\section{PENDAHULUAN}

Islam adalah agama dakwah. Artinya agama yang selalu mendorong pemeluknya untuk senantiasa aktif melakukan kegiatan dakwah, bahkan maju mundurnya umat Islam sangat bergantung dan berkaitan erat dengan kegiatan dakwah yang dilakukannya. Dengan kata lain kegiatan dakwah menempati posisi yang tinggi dan mulia dalam kemajuan agama Islam. Aktivitas dakwah merupakan proses penyampaian ajaran agama Islam terhadap umat manusia disetiap ruang dan waktu dengan berbagai metode dan media yang sesuai dengan situasi dan kondisi para penerima (mad'u) dakwah tersebut (AS, 2009: 145). Jika dianalisa keseluruhan terhadap sebuah proses dakwah, maka dapat dilihat bahwa pentingnya keselarasan antara metode dakwah dengan tujuan dakwah. Pentingnya metode dakwah juga memperlihatkan bahwa tata cara dalam berdakwah lebih penting dari materi dakwah itu sendiri. Kegiatan pengajian di masjid AlFurqon merupakan sebuah aktivitas sosial keagamaan yang berperan sebagai wadah untuk memberikan nasihat juga motivasi kepada para jamaah lanjut usia untuk terus melakukan perubahan, perbaikan serta 
peningkatan dalam beribadah untuk itu hipotesis dalam penelitian ini adalah apa metode dakwah yang digunakan untuk jamaah lanjut usia di masjid Al-Furqon dan apa faktor pendukung dan faktor penghambat dakwah kepada jamaah lanjut usia di masjid Al-Furqon

Sebelum lebih jauh memahami istilah "Metode dakwah", terlebih dahulu perlu diuraikan masingmasing makna dari istilah tersebut. Hal ini diharapkan dapat membantu memberikan pemahaman secara utuh tentang arah penelitian ini. Pengertian metode dalam Kamus Besar Bahasa Indonesia (KBBI) dimaknai sebagai cara teratur yang digunakan untuk melaksanakan suatu pekerjaan agar tercapai sesuai dengan yang dikehendaki, cara kerja yang bersistem untuk memudahkan pelaksanaan suatu kegiatan guna mencapai tujuan yang ditentukan. Sementara dakwah secara lughawi berasal dari kata da'a- yad'uda'watan, yang berarti memanggil, mengajak, menyeru, memohon, mengundang dan berdoa dengan mengubah kata (Basit, 2013: 43). Menurut Muhammad Natsir definisi dakwah mengandung arti kewajiban yang menjadi tanggung jawab seorang muslim dalam amar ma'ruf dan nahi munkar (Wahidin, 2011: 3). Sedangkan menurut M Arifin, dakwah mengandung pengertian sebagai suatu kegiatan ajakan, baik dalam bentuk lisan, tulisan tingkahlaku dan sebagainya, yang dilakukan secara sadar serta berencana dalam usaha mempengaruhi orang lain. Baik secara individual maupun kelompok, agar timbul dalam dirinya suatu pengertian, kesadaran, sikap penghayatan serta pengalaman terhadap ajaran Agama sebagai massage (pesan) yang disampaikan kepadanya tanpa ada unsur paksaan (Sukayat, 2015: 8-9). Dari pengertian di atas dapat penulis simpulkan bahwa setiap muslim memiliki kewajiban dalam menyampaikan dan mengajarkan Islam kepada setiap manusia yang ada dimuka bumi ini, tanpa ada unsur paksaan. Adapun pengertian metode dakwah adalah cara tertentu yang dilakukan oleh seorang penceramah kepada mad'u untuk mencapai suatu tujuan atas dasar hikmah dan kasih sayang. Hal ini mengandung arti bahwa pendekatan dakwah harus bertumpu pada suatu pandangan human oriented menempatkan penghargaan yang mulia atas diri manusia (Munir, 2006: 7).

Tujuan dari penelitian ini untuk mengetahui metode dakwah yang digunakan pada jamaah lanjut usia dan faktor pendukung serta penghambat dakwah kepada jamaah lanjut usia di Masjid Al-Furqon Haurgeulis Indramayu.

\section{METODE}

Jenis penelitian ini adalah penelitian lapangan dan metode yang digunakan pada penelitian ini adalah metode kualitatif. Populasi pada penelitian ini adalah Seluruh jamaah lanjut usia di Masjid Al-Furqon yang berumur 60 Tahun keatas berjumlah 20-25 orang lansia. Sumber data yang digunakan yakni data primer dan data sekunder. Data primer diperoleh langsung dengan cara observasi, wawancara terstruktur dan dokumentasi mengenai tinjauan yang dijadikan fokus penelitian ini. Data sekunder diperoleh dari riset kepustakaan yang dijadikan sebagai landasan teori guna sebagai acuan agar peneliti tidak melewati batas dalam menganalisis data yang diperoleh dilapangan. Format pengolahan data menggunakan metode deskriptif yang akan mampu menghasilkan berbagai informasi kualitatif yang deskriptif. Pendekatan kualitatif kaitannya dengan penelitian ini akan digunakan untuk menganalisis metode dakwah pada jamaah lanjut usia di masjid Al-Furqon Haurgeulis.

\section{HASIL DAN PEMBAHASAN}

Dari hasil observasi dan wawancara dapat diketahui bahwa masjid Al-Furqon terletak dipusat kota kecamatan Haurgeulis. Lokasi masjid Al-Furqon sangat strategis yaitu di jalan alun-alun barat, No 03 Haurgeulis, kabupaten Indramayu, Jawa Barat. Berawal dari sebuah langgar kecil di pojok kampung, yang didirikan oleh warga serta dimotori oleh Muhammadiyah ranting Haurgeulis, masjid Al-Furqon ini dibangun. Peletakan batu pertama pembangunan masjid ini pada tahun 1968. Masjid Al-Furqon dibangun di atas tanah seluas $2.482 \mathrm{~m}^{2}$ merupakan tanah wakaf Hj Siti Maryam. Donatur pembanguan masjid AlFurqon adalah Bapak H Sukardi dan warga sekitar masjid. Masjid Al-Furqon berada diperempatan jalan, menjadikan masjid ini cukup mudah untuk dijumpai. Masjid Al-Furqon memiliki satu lantai, satu serambi dan satu menara, kemudian di samping serambi terdapat bangunan sekretariat masjid Al-Furqon, madrasah diniyah awaliyah (MDA), terdapat dua tempat wudhu, sebelah selatan tempat wudhu nisa' (wanita) dan disebelah utara tempat wudhu rijal (laki-laki). Sedangkan total daya tampung jamaah masjid adalah sekitar 500 orang.

Aktivitas masjid Al-Furqon semakin tahun semakin ramai, jamaahnya pun bukan hanya dari lingkungan masjid saja, tapi dari daerah luar dari Desa Haurgeulis. Sampai sekarang, kondisi masjid AlFurqon yang sudah masuk setengah abad lamanya semakin membaik dengan beberapa fasilitas yang memadai untuk aktivitas ibadah dan kegiatan-kegiatan lain. Sebagaimana kita ketahui bahwa masjid merupakan sebuah bangunan, tempat ibadah umat Islam, yang digunakan umat terutama sebagai tempat dilangsungkannya shalat berjamaah (Syahidin, 2003: 121). Kata masjid terulang sebanyak dua puluh delapan kali di dalam Alquran. Masjid juga disebut Baitullah atau "Rumah Allah" .Seluruh bumi Allah 
adalah tempat sujud sebagaimana dikukuhkan oleh sabda Nabi Muhammad Saw:

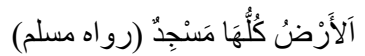

Artinya: seluruh muka bumi ini telah dijadikan Masjid bagiku. (HR.Muslim) dalam kitab Al-Jami' As-Shohih.

Pernyataan Nabi Muhammad Saw tersebut menunjukkan bahwa pelaksanaan ibadah shalat yang merupakan penghambaan, pengabdian dan ketaatan seorang hamba kepada sang pencipta tidaklah terikat dengan lokasi tertentu karena pelaksanaan ibadah shalat bisa saja dilaksanakan di rumah, kantor, hutan, gunung, kendaraan bahkan pinggir jalan sekalipun. Tempat-tempat tersebut merupakan masjid (tempattempat sujud) bagi umat Islam (Castrawijaya, 2010: 2). Masjid adalah rumah Allah (Baitullah) yang dibangun sebagai sarana untuk mengingat, mensyukuri dan menyembah Allah SWT.

Masjid Al-Furqon merupakan masjid kauman yang terbilang megah, Yaitu Masjid yang berada ditingkat Kelurahan atau Desa menjadi pusat kegiatan keagamaan tingkat Kelurahan atau Desa. Pendirian bangunan Masjid ini umumnya sepenuhnya dibiayai oleh pemerintahan Desa dan swadaya masyarakat setempat, kalaupun ada sumbangan dari Pemerintah relatif sedikit. DKM memiliki posisi strategis dalam pembangunan masyarakat dan aktivitas di lingkungan Masjid, oleh sebab itu DKM harus mampu mengembangkan kapasitas dengan memahami tugas melalui manajemen yang baik. DKM Masjid AlFurqon Haurgeulis terdiri dari remaja hingga kalangan profesional. DKM yang diisi oleh lintas usia ini membuat kinerja mereka optimal. Keoptimalan kinerja tersebut dikarenakan program kerja yang disusun mampu mengakomodir kebutuhan seluruh lapisan masyarakat dari anak-anak hingga dewasa. Program yang disusun dan dijalankan DKM masjid Al-Furqon Haurgeulis Indramayu berpengaruh pada jumlah jamaah yang shalat di masjid tersebut.

Program pengajian di masjid Al-Furqon adalah salah satu wujud dalam memakmurkan masjid. Memakmurkan masjid tidak sekedar menggelar sholat berjamaah lima waktu sehari, tetapi juga menghidupkan sebagaimana fungsi masjid. Hendaknya masjid harus mempunyai daya tarik yang kuat terhadap masyarakat disekitarnya, agar mereka tidak segan untuk datang ke masjid. Fungsi masjid itu selain dijadikan tempat untuk urusan keagamaan, masjid juga mengurusi kegiatan ekonomi, sosial, keilmuan dan administrasi Negara (Sutarmadi, 2012: 1).

Masyarakat Haurgeulis merupakan masyarakat urban, banyak sekali pendatang dari Jawa, Sunda bahkan dari Padang pun ada. Awal mula munculnya pengajian di masjid Al-Furqon karena adanya dakwah respon dari masyarakat sekitar, kemudian menggeliatnya keberagamaan dan spiritual masyarakat meningkat. Masjid sangat berperan aktif dalam kegiatan dakwah, karena masjid merupakan jantung kehidupan umat Islam, yang selalu berdenyut untuk menyebarluaskan dakwah Islamiyah, masjid dan dakwah merupakan dua faktor yang erat sekali hubungannya satu sama lain, saling mengisi diantara keduanya. Dengan demikian masjid Al-Furqon dapat berperan sebagai tempat atau media dakwah Islamiyah. Dakwah ini pada dasarnya meliputi berbagai aspek kegiatan, termasuk didalamnya masalah sosial, budaya, pendidikan dan sebagainya. Program DKM mulai membentuk pengajian di masjid AlFurqon ini sekitar 20 Tahunan.

Dalam awal perjalanannya kegiatan pengajian ini dilaksanakan dengan berpindah-pindah tempat untuk berdakwah, saat itu rombongan jamaah masjid Al-Furqon berdakwah sampai ke Koroba Kroya, di sana pengkristenisasian sangatlah kuat dan sudah banyak menyebar, sasarannya kebanyakan adalah anak kecil. Atas perjuangan jamaah terdahulu dalam menyebarkan Agama Islam, mereka membangun masjid yang bersebelahan dengan gereja, mereka saat ini hidup rukun dan mengedepankan toleransi. Seiring berjalannya waktu akhirnya mereka menetapkan untuk mengadakan pengajian di Masjid Al-Furqon yang saat itu diadakan satu Minggu sekali, dirasa kurang cukup untuk memenuhi gairah keagamaan masyarakat pada saat itu maka sepuluh Tahun terakhir ini ditetapkanlah pengajian rutinan setiap dua minggu sekali, yaitu malam Ahad dan malam Rabu. Kegiatan di Masjid Al-Furqon sangatlah beragam, pengurus Masjid mengevaluasi setiap kegiatan, jika ada respon baik dari masyarakat maka kegiatan tersebut terus diselenggarakan, namun jika kurangnya respon masyarakat terhadap kegiatan tersebut maka ditiadakan.

Pengajian rutinan ini mendapatkan respon baik dari jamaah masjid Al-Furqon, baik itu dari jamaah tetap maupun bukan jamaah tetap. Secara khusus memang tidak ada pengajian khusus untuk jamaah lanjut usia, akan tetapi pada kenyataannya di masjid Al-Furqon para remajanya kurang antusias dalam berkontribusi mengikuti kajian rutin malam Ahad dan malam Rabu. Secara tidak langsung jamaah sudah memetakkan sendiri sesuai dengan klasifikasi sesuai usianya. Jamaah lanjut usia di masjid Al-Furqon terdiri dari berbagai kalangan status sosial mulai dari pedagang sampai pensiunan guru. Sholat berjamaah lima waktu merupakan rutinitas yang menjadi sebuah keharusan bagi mereka, megingat seusia mereka tidak banyak lagi kegiatan di luar rumah.

Proses dakwah dari dulu sampai sekarang membuahkan hasil, bahkan berimbas pada 13 Masjid diwilayah Haurgeulis. Masjid Al-Furqon secara kultur adalah Muhammadiyah, namun semua organisasi kelompok-kelompok seperti Nahdatul Ulama, Persatuan Islam, Salafi Jihadi, PKS, kelompok Tarbiyah 
dan yang lainnya, semua organisasi dinaungan Al-Furqon. Namun ada beberapa organisasi atau kelompok yang memang tidak diizinkan ada di Al-Furqon, seperti Syi'ah, Ahmadiah, Islam Liberal yang saat ini menjadi Islam Nusantara, seperti diketahui semakin dalam mempelajari Islam Nusantara bukan malah semakin komitmen dengan keIslamannya.

\section{Peningkatan Kualitas Keagamaan Jamaah Lanjut Usia}

Pengertian peningkatan secara epistimologi adalah meningkatkan derajat taraf, yang berarti lapisan dari sesuatu yang kemudian membentuk menjadi susunan, secara umum peningkatan merupakan upaya untuk memenambah derajat, tingkat, kualitas dan kuantitas. Peningkatan juga dapat berarti pemenambahan keterampilan dan kemampuan agar menjadi lebih baik, Pada masa lansia, kecenderungan untuk mengakui kebenaran ajaran Agama makin meningkat, kecenderungan hawa nafsu makin terkendali, kebutuhan terhadap gemerlapnya dunia makin berkurang, dan keyakinan akan kehancuran dunia makin nyata dan kekekalan akhirat makin terasa. Dalam buku psikologi Agama Djalaluddin menuliskan beberapa ciri-ciri keberagaman manusia pada lanjut usia secara garis besarnya adalah (Djalaluddin, 1998: 97): (1) Kehidupan keberagamaan pada lansia sudah mencapai tingkat kemantapan. (2) Munculnya pengakuan terhadap realitas tentang kehidupan akhirat secara lebih sungguh-sungguh. (3) Sikap keberagamaan cenderung mengarah kepada kebutuhan saling cinta antara sesama manusia, serta sifatsifat luhur. (4) Meningkatnya kecenderungan untuk menerima pendapat keagamaan. (5) Timbulnya rasa takut kepada kematian yang sejalan dengan pertambahan lanjut usia. (6) Perasaan takut kepada kematian ini berdampak pada peningkatan pembentukan sikap dan kepercayaan terhadap kehidupan abadi (akhirat).

Kesadaran dan gairah mereka dalam mengamalkan ilmu yang didapat dari waktu-kewaktu mengalami perkembangan baik dilihat dari kualitas maupun kuantitas. Sangat terlihat jelas dari semangat jamaah lanjut usia untuk sholat berjamaah lima waktu di masjid Al-Furqon. Di usia lanjut kesadaran akan sholat berjamaah terbilang tinggi, kemudian juga kepedulian terhadap masalah keagamaan seperti, dakwah, ekonomi, sosial juga tinggi. Semisal dalam bidang sosial apabila ada jamaah yang sedang sakit, jamaah yang lain beserta pengurus masjid datang untuk menjenguk mereka, walaupun sedang di luar Daerah. Dibidang dakwah jamaah banyak mengalami peningkatan, seperti menambahnya wawasan, sholat semakin khusuk, konsisten untuk saum sunnah, kemudian mengamalkan apa yang disampaikan oleh penceramah baik yang berhubungan dengan, ubudiyah maupun uluhiyah, itu semua mereka dalami dan mempraktikkan sesuai dengan kemampuan mereka.

Dengan segala keistimewaan yang dimiliki oleh lansia tidaklah cukup apabila hanya menggunakan metode ceramah saja. Metode tanya jawab dan metode praktik mempermudah jamaah lanjut usia dalam memahami isi pesan dakwah yang disampaikan dan pemilihan metode berpengaruh terhadap peningkatan kualitas keagamaan jamaah lansia. Dari hasil wawancara yang peneliti lakukan dapat diketahui bahwa kualitas jamaah di masjid Al-Furqon tidak diragukan lagi konsistensi dari setiap individu untuk terus memperbaiki diri menjadi lebih baik semakin meningkat, kesadaran dan motivasi melaksanakan ibadah semakin serius.

\section{Metode Dakwah yang Digunakan untuk Jamaah Lanjut Usia}

Metode berasal dari Bahasa Yunani yaitu "Methodos" yang berarti cara atau jalan yang ditempuh, sehubungan dengan upaya ilmiah maka metode menyangkut masalah cara kerja atau dapat memahami objek yang menjadi sasaran ilmu yang bersangkutan. Fungsi metode berarti sebagai alat untuk mencapai tujuan. Menentukan metode dalam berdakwah tentunya akan mengantarkan pada kesuksesan asimilasi sikap penceramah dan mad'u dalam proses kegiatan dakwah yang berdampak pada keberhasilan dakwah dengan kata lain materi dakwah dapat dicerna dengan baik sehingga harapan akan penghayatan dan penerapannya dapat terlihat hasilnya. Berdakwah kepada objek dakwahnya yakni lanjut usia, seorang penceramah harus memiliki kompetensi yang mumpuni, pengalaman berdakwah yang luas, sensitive dan mampu melihat cela pada sisi kehidupan lansia untuk menjamin keberhasilan dakwah.

DKM Al-Furqon tidak memberikan patokan khusus tentang metode apa yang harusnya digunakan kepada jamaah, utamanya jamaah lanjut usia. Jadi metode yang pada umumnya banyak digunakan adalah metode ceramah, metode tanya jawab dan metode aplikatif, adapula metode muroja'ah bila diperlukan.

\section{Metode Ceramah}

Metode ceramah merupakan salah satu metode yang paling banyak digunakan oleh para penceramah. Dalam sejarah Islam Rasulullah Saw dalam menyampaikan risalahnya, beliau juga menggunakan metode ceramah, baik secara sembunyi-sembunyi ataupun secara terang-terangan. Di masjid Al-Furqon setiap penceramah memiliki gaya tersendiri dalam berdakwah, dengan latar belakang pendidikan yang berbeda juga mempengaruhi cara penyampaian dalam berdakwah, ada yang menyampaikan pesan dakwah itu secara menggebu-gebu, baginya pesan yang disampaikan itu sangat penting dan tidak bisa disampaikan 
secara lemah lembut, adapula yang menyampaikan dakwahnya dengan lemah lembut, tanpa intonasi dan terbilang lebih monoton. Kesemua itu tergantung pada kepribadian penceramah yang akan mempengaruhi berhasil tidaknya dakwah tersebut.

Menurut Muriah metode dakwah terbilang efektif apabila: berkaitan dengan acara-acara ritual seperti khutbah Jum'at, khutbah Hari Raya, dikatakan efektif karena hal ini merupakan dari ibadah. Kajian atau materi yang disampaikan berupa tuntunan praktis dan disampaikan kepada jamaah yang terbatas baik jumlah maupun luasnya ruangan. Disampaikan dalam konteks sajian terprogram secara rutin dan memakai kitab sebagai sumber kajian. Disampaikan dengan sistem dialog dan bukan monologis, sehingga audiens dapat memahami materi dakwah secara tuntas, setidaknya metode ceramah masih dikatakan efektif apabila disertai dengan tanya jawab (Muriah, 2002: 72).

Beberapa jamaah yang peneliti wawancarai mengatakan bahwa metode ceramah ini sudah sangat relevan dengan seusia mereka, didukung dengan metode yang lain yaitu metode tanya jawab, dan juga metode praktik, metode ini dijadikan sebagai pelengkap dari metode ceramah, metode ini merupakan satu kesatuan dalam meningkatkan pemahaman para jamaah lansia, sehingga apa yang didapat dari pengajian tersebut dapat diaplikasikan dalam kehidupan sehari-hari.

\section{Metode Tanya jawab}

Metode tanya jawab adalah menyampaikan materi dakwah dengan mendorong sasarannya untuk menyatakan suatu masalah yang dirasa belum mengerti dan penceramah sebagai penjawabnya (Aziz, 2004: 359). Di masjid Al-Furqon metode tanya jawab digunakan secara fleksibel, metode ini dimaksudkan untuk melayani masyarakat sesuai kebutuhannya. jika jamaah lanjut usia ingin bertanya perihal keagamaan, biasanya mereka langsung datang kepada penceramah untuk bertanya secara langsung, dengan menggunakan lisan. Metode ceramah akan lebih efektif apabila metode tersebut disertai dengan metode tanya jawab yang diajukan oleh jamaah lanjut usia.

\section{Metode Aplikatif}

Masyarakat selalu mengerjakan sesuatu dengan caranya mereka sendiri. Persoalannya sangatlah sederhana, masyarakat awam pada umumnya mereka mempelajari sesuatu berdasarkan pengalaman yang tidak ada dasarnya, hanya sekedar ikut-ikutan tanpa tau dasar ilmu agama. Semisal tentang wudhu, kebanyakan orang melakukan wudhu hanya berdasarkan apa yang dia tahu dan apa yang dia lihat, namun di Al-Furqon memberikan pemahan kepada jamaah lanjut usia bahwa wudhu itu ada aturan tersediri dalam ilmu fiqh dan juga terdapat pahala sunnah jika kita mengerjakan itu. Jamaah lanjut usia di masjid Al-Furqon sangat terbantu dengan adanya metode aplikatif ini, walaupun secara latar belakang pendidikan banyak diantara mereka merupakan pensiunan guru, akan tetapi mereka juga menyadari bahwa pengetahuan tentang agama sangatlah minim, begitu juga dengan jamaah lanjut usia yang sebagian dari mereka tidak sekolah, metode ini sangat membantu, banyak pengetahuan yang mereka dapat setelah bertanya dan dipraktikkan oleh penceramah.

Metode ini sebagai pelengkap dari metode ceramah dan metode tanya jawab biasanya diterapkan apabila ada keterangan yang belum dipahami oleh jamaah lanjut usia di masjid Al-Furqon. Biasanya yang dijadikan materi dalam metode ini adalah praktik sholat, thaharah, Wudhu' intinya yang berkaitan dengan Fiqih Ibadah (Asep, 2002: 177).

Seorang penceramah atau lembaga dakwah yang ingin efektif dalam misinya, harus memahami persoalan yang dihadapi masyarakat. Dengan demikian seorang penceramah dalam menentukan dan mempergunakan metode harus terlebih dahulu menyelidiki metode yang dapat dipandang menghasilkan sesuatu yang diinginkan, sudah sangat jelas bahwa sukses-tidaknya para penceramah bergantung pada kemampuannya dalam menumbuhkan minat sebagian orang dalam mengarungi hidup yang lebih baik, pengalaman mengajarkan bahwa kesuksesan berdakwah bergantung pada efektivitas dan selektivitas penceramah dalam memilih dan menggunakan metode.

\section{Faktor pendukung dan penghambat yang dihadapi ketika berdakwah kepada lanjut Usia}

Suatu kegiatan tidak akan pernah terlepas dari adanya dukungan dan hambatan, begitu juga dengan kajian rutinan di masjid Al-Furqon ada faktor pendukung dan hambatannya juga. Faktor pendukung pengajian di masjid Al-Furqon, antara lain adalah:

\section{Sarana Dan Prasarana}

Seperti pengajian pada umumnya salah satu faktor yang mendukung terlaksananya pengajian ini dapat dilihat dari sarana dan prasarana seperti fasilitas yang tersedia, ada microfon, meja khusus pengajian, kabel, kipas, camilan-camilan yang disediakan oleh pihak DKM. pengeras suara luar dan dalam, dengan menggunakan speaker dalam dan luar diharapkan masyarakat sekitar masjid juga dapat menyimak pengajian sekalipun tidak bisa hadir langsung di masjid Al-Furqon. Untuk pengajian setiap bulannya 
terkadang menggunakan proyektor agar fokus dalam memaparkan materi.

\section{Waktu Pelaksanaan Kajian}

Waktu kajian dilaksanakan setiap malam Ahad dan malam Rabu setelah sholat maghrib. Sembari menunggu waktu sholat isya' kajian rutinan ini dilaksanakan, hal itu memungkinkan untuk jamaah tidak pulang setelah selesai melaksanakan sholat maghrib. Banyak para jamaah usia menengah dan usia lanjut duduk diserambi masjid untuk mendengarkan ceramah yang disampaikan oleh ustadz yang bertugas. Waktu yang ditetapkan oleh DKM Al-Furqon sangat pas untuk jamaah bapak-bapak, mengingat jika dilaksanakan di siang hari masih banyak diantara mereka melakukan kegiatan dirumah maupun diluar rumah. Masalah penetapan waktu juga berpengaruh terhadap peningkatan jumlah jamaah, Setiap tahunnya mengalami peningkatan jumlah jamaah secara signifikan.

\section{Penggunaan Bahasa Daerah}

Faktor pendukung yang mempermudah pesan dakwah tersampaikan lainnya adalah tidak memberikan pesan dakwah yang berat kepada jamaah, agar apa yang disampaikan dapat dipahami oleh jamaah lansia, cara penyampaiannya tidak monoton sehingga jamaah tidak mudah jenuh karena kurang dapat memahami materinya, daya tangkapnya sudah berbeda dengan anak muda, materi ringan dapat membantu mereka yang sekiranya tidak mudah lupa, walaupun sebagian diantara jamaah lansia berpendidikkan tinggi tetap diselipkan Bahasa Indramayu supaya lebih mengena, mengingat kapasitas intelektual umat yang berbeda.

\section{Toleransi}

Aktivitas di masjid Al-Furqon semakin tahun semakin ramai, jamaahnya pun bukan hanya dari lingkungan masjid saja, tetapi luar daerah dari Desa Haurgeulis pun juga ada. Hal itu dilatarbelakangi oleh adanya toleransi yang sangat kuat. Masjid Al-Furqon secara kultur adalah Muhammadiyah, Namun semua organisasi kelompok keagamaan seperti Nahdhatul Ulama, Persatuan Islam, Salafi Jihadi dan lain sebagainya ikut serta di dalamnya. Tidak adanya fanatisme kelompok menjadikan Al-Furqon sebagai masjid yang terbilang sangat ramai.

Terlalu berhati-hati dalam menuntut ilmu akan membuat diri kita rugi. Ketika fanatik terhadap sesuatu, maka banyak kebaikan yang tidak bisa diambil. Kefanatikan terhadap sesuatu hal berdampak negatif bagi penuntut ilmu, di Al-Furqon mengedepankan disiplin ilmu dan menyampingkan fanatisme kelompok. Setiap organisasi, partai ataupun kelompok Islam ada sayyiat dan ada hasanat-Nya, jangan dilihat keburukannya, lihatlah kebaikannya, misalkan kelompok Salafi disisi kajiannya, ketelitiannya dalam kajian melihat hadis-hadis shohih maupun dhaif dan juga di dalam pendapat Fiqihnya terbilang rajih. kelompok PKS, tarbiyah bagus di dalam menata rumah tangganya, pergaulannya dan sebagainya.

\section{Dukungan Keluarga}

Setiap kegiatan yang dilakukan oleh orang lanjut usia, dibutuhkan dukungan dan motivasi agar menjadikan inspirasi bagi orang lanjut usia untuk tetap beraktivitas dan berkreasi, dengan begitu pengaruh negatif seperti merasa kesepian, depresi ataupun ada rasa tidak dihargai itu tidak akan muncul. Adapun hambatan-hambatan yang menyebabkan pesan tersebut tidak sampai kepada jamaah adalah pemilihan metode yang kurang sesuai dengan klasifikasi mad'u. Menyampaikan dakwah kepada kalangan lansia bukan hal yang terbilang mudah, karena kapasisitas daya terima setiap jamaah berbeda-beda, dengan keterbatasan intelektual, menjadikan kendala untuk menentukan barometer sukses tidaknya dakwah yang disampaikan penceramah.

Pengkolaborasian bahasa dijadikan alternatif untuk mempermudah pesan dakwah tersampaikan pada jamaah lanjut usia, baik itu Bahasa Sunda, Jawa, Bahasa Indramayu dan Bahasa Indonesia. Pengajian ini diselenggarakan tidak dalam ruangan yang tertutup, melainkan di Serambi masjid yang menjadikan kurangnya fokus jamaah dalam menerima pesan dakwah yang disampaikan oleh penceramah. Adapun kendala yang dihadapi oleh jamaah lanjut usia dalam menerima dakwah adalah:

\section{Psikologis}

Seiring bertambahnya usia banyak sekali faktor-faktor yang menyebabkan para lansia mengalami banyak permasalahan, baik itu dilihat dari segi pasikologis maupun segi fisik, jika dilihat dari segi psikologis maka permasalahan yang dihadapi para lansia adalah:

\section{Kesepian}

Kehilangan pasangan hidup atau berada jauh dengan anak-anak yang telah mempunyai kesibukannya masing-masing kadang membuat para lansia kesepian. Namun ada juga para lansia yang memiliki 
aktivitas sosial yang tinggi, tidak merasa kesepian ketika ditinggal atau jauh dengan orang yang dicintainya.

\section{Duka Cita}

Akibat kehilangan orang yang dicintai adalah hal yang dapat menimbulkan depresi yang sangat mendalam pada lansia sehingga memicu gangguan fisik dan kesehatannya, depresi dikarenakan duka cita biasanya bersifat membatasi diri.

\section{Depresi}

Beragam permasalahan hidup seperti kemiskinan, penyakit yang tidak berujung baik, kematian pasangan, keturunan yang tidak bisa merawatnya dapat menyebabkan depresi.

\section{Fisik}

Fisik seseorang sangat mempengaruhi terhadap kehidupannya, utamanya untuk lansia, kondisi fisik mereka mengalami banyak perubahan seperti penglihatan berkurang, pendengaran berkurang, daya tahan tubuh yang semakin lemah, dan lainnya membuat jamaah lansia kesulitan dalam mengikuti pengajian. Seorang ustadz harus pelan-pelan dalam menyampaikan dakwah. Selain itu, jamaah lansia juga ada yang sudah sakit-sakitan sehingga tidak bisa menghadiri setiap pengajian yang diadakan walaupun semangat jamaah lansia masih membara untuk mengikuti acara pengajian tersebut. Berkurangnya satu jamaah apabila ada salah satu dari mereka tidak berangkat pasti ditanya oleh jamaah lainnya, hubungan erat yang mereka jalin bukan hanya sekedar pertemanan saja, sudah diibaratkan sebagai anggota tubuh, jika ada salah satu yang sakit pasti yang lain juga merasakan sakit, di masjid Al-Furqon apabila ada jamaahnya yang sedang sakit, mereka membesuk bersama-sama untuk memberikan semangat, mendoakan bersama agar bisa kembali lagi ikut berjamaah dan melakukan aktifitas lagi di masjid Al Furqon.

\section{KESIMPULAN}

Simpulan dapat bersifat generalisasi temuan sesuai permasalahan penelitian, dapat pula berupa rekomendatif untuk langkah selanjutnya. Yang dapat disimpulkan dari pembahasan diatas menjelaskan bahwa metode yang digunakan adalah metode nasihat dalam bentuk ceramah, tanya jawab, dan metode aplikatif, DKM berharap dengan penggunaan metode tersebut jamaah lansia dapat mengaplikasikannya dalam kehidupan sehari-hari. Sedangkan yang menjadi faktor pendukung dakwah kepada jamaah lanjut usia adalah (a) Sarana dan prasarana yang memadai (b) Waktu pelaksanaan kajian sangat tepat yakni dilaksanakan setelah usai sholat maghrib berjamaah (c) Penggunaan bahasa daerah sebagai pendukung tersampainya pesan dakwah yang disampaikan oleh penceramah (d) Toleransi terhadap kelompok atau organisasi lain yang tidak sepaham dengan kultur masjid Al-Furqon (f) Dukungan keluarga, selain ada kemauan dari jamaah itu sendiri mereka juga ada dukungan penuh dari keluarga, hal itu memotivasi mereka untuk istiqomah dalam mengikuti kajian di masjid Al-Furqon. Adapun faktor penghambat dalam menyampaikan pesan dakwah kepada jamaah lansia dilihat dari segi psikologis dan fisiknya, (a) Dilihat dari segi psikologis yaitu, mengalami kesepian (b) merasakan dukacita (a) mengalami depresi (b) Jika dilihat dari segi fisik, berkurangnya daya pendengaran, penglihatan serta daya tahan tubuh yang semakin lemah sehingga mudah terserang penyakit. Oleh karenanya hal yang menghambat mereka dalam mengikuti kajian rutinan membuat jamaah lanjut usia kesulitan dalam mengikuti pengajian rutinan di masjid Al-Furqon.

\section{REFERENSI}

Asep, Usman Ismail dan Cecep Castrawijaya.2010. Manajemen Masjid, Bandung: Angkasa

Aziz, 2004. Ilmu Dakwah. Jakarta: Kencana

Basit, Abdul. 2013. Filsafat Dakwah Jakarta: Rajawali Pers

Departeman Agama Direktorat Urusan Agama Islam dan Pembinaan Syriah Direktorat bimbingan masyarakat Islam, 2008

Djalaluddin. 1998. Psikologi Agama. Jakarta: Rsajawali Press

Enjang AS, Aliyudin. 2009. Dasar-Dasar Ilmu Dakwah: Pendekatan Filosofis dan Praktis. Bandung: Widya Padjajaran

Munir, Muhammad. 2006. Metode Dakwah, Jakarta: Prenada Media

Muriah, Siti. Metodologi Dakwah Kontemporer. Yogjakarta: Mitra Pustaka, 2002, 72

Muslim. Al-Jami’ As-Shohih Bab Shalat. Beirut: darul fiqr, 131 
Sukayat, H Tata. 2015. Ilmu Dakwah.perspektif Filsafat Mabadi ‘Asyarah Bandung: PT. Remaja Rosdakarya Offset,

Sutarmadi, Ahmad. Menejemen Masjid Kontemporer. Jakarta: Media Bangsa, 2012, 1

Syahidin. 2003. Pemberdayaan Umat Berbasis Masjid. Bandung: AlfabetaSetia

Wahidin, Saputra. 2011. Pengantar Ilmu Dakwah Jakarta: PT RsajaGrafindo Persada 